\title{
Sociobiology
}

RESEARCH ARTICLE - WASPS

\section{Post-embryonic Development of Mischocyttarus latior (Fox) (Hymenoptera: Vespidae)}

\author{
DSS CECÍLIO ${ }^{1}$, AA DA ROCHA², E GIANNOTTI ${ }^{1}$ \\ 1 - Universidade Estadual Paulista (UNESP), Rio Claro, SP, Brazil \\ 2 - Universidade Federal da Bahia, Vitória da Conquista, BA, Brazil
}

\section{Article History \\ Edited by \\ Gilberto M. M. Santos, UEFS, Brazil \\ Received 21 April 2014 \\ Initial acceptance 24 May 2014 \\ Final acceptance 10 November 2014}

\section{Keywords}

Larva, lobes, Mischocyttarini, Polistinae.

\section{Corresponding author:}

Agda Alves da Rocha

Universidade Federal da Bahia

Campus Anísio Teixeira

Rua Rio de Contas, Quadra 17, Lote 58,

Bairro Candeias, CEP 45055-090,

Vitória da Conquista, Bahia, Brazil

E-Mail: rocha.agda@gmail.com

\begin{abstract}
Mischocyttarus latior (Fox) occurs in Bolivia and Brazil and has been recorded in Cerrado areas from southeast Brazil. The objectives of the present study were to describe the immature stages of $M$. latior, determine the development time of the immature stages and determine which factors affect its duration. Daily mappings were performed from March 1994 to August 1995 in 22 nests. Two nests were also collected and dissected to characterize immatures. Larvae presented five instars and unlike most Mischocyttarus, $M$. latior has only a single lobe on the abdominal sternite, which is vestigial in third instar, emergent in fourth instar and fully developed in the fifth instar larvae. The mean duration of the immature stages (from egg laying to adult emergence), was $67.38 \pm 9.41$ days, a longer period than the total duration of the immature stages of other previously studied species. The development time of the immatures was variable, depending on the colony development stage, with development times being quicker in pre-emergence colonies.
\end{abstract}

\section{Introduction}

Mischocyttarus latior (Fox) occurs in Bolivia and has been registered in the Brazilian States of Mato Grosso, Minas Gerais and São Paulo (Richards, 1978). This species has also been recorded in Cerrado areas (a type of savanna) in the southeast region of Brazil (Elpino-Campos et al., 2007; Lima et al., 2010).

There are few documented descriptions of this species and at first glance, M. latior adults are very similar to Polybia ignobilis (Haliday). Richards (1978) provides one of the few descriptions of $M$. latior adults, describing the species as a black wasp, with "ferruginous" fore tibia. The same author reports a narrow margin of metanotum, and a single dorsal streak on the mid coxa and two on the hind coxa. Richards (1978) also observed yellow dots on the thorax, at the articulation points of the mid and hind legs, but also highlights "striking" variation in the morphology of the adults he studied. In order to increase our knowledge of M. latior biology the objective of the present study was to describe $M$. latior immatures, determine the period of development of the immature stages and determine which factors affect its duration (seasons, position of cells and stage of development).

\section{Materials and Methods}

Daily mappings were performed from March 1994 to August 1995 in 22 M. latior nests, located in the campus of the São Paulo State University ("Universidade Estadual Paulista Júlio de Mesquita Filho"), and in the District of Ferraz, in the municipality of Rio Claro, São Paulo State, Brazil (22²4'36"' S; 47'33'36" W). At each visit the number of cells was recorded and their content classified into four groups: empty, egg, larva, or pupa. The position of the egg in the cell (Giannotti \& Fieri, 1991) and the position of cells occupied by immatures were also recorded. In addition the nest size was classified (small: up to 30 cells and large: greater than 30 cells) and colony development stage (pre- and postemergence) were also recorded. To describe the immatures two nests were collected. All the eggs, larvae and pupae were removed from the two nests and morphometric measurements taken with the aid of a stereomicroscope coupled to a micrometer viewer. The morphometric measurements were: head capsule of the larvae and largest diameter and length of the eggs.

The Kruskal-Wallis test was used to check for significant differences in the mean duration of immature stages between 
annual seasons. The Mann-Whitney U test was used to test for differences in the duration of the immature stages and position in the cells (center or periphery) and colony development stage (pre- and post-emergence) (Siegel \& Castellan, 2006).

\section{Results and Discussion}

\section{Description of Immature Stages}

The appearance of $M$. latior eggs was typical of members of the Vespidae family. The eggs were white, elongated, narrower at the base and slightly curved and dilated at the tip. $M$. latior eggs were attached to one of the angles of the nest cell walls by an adhesive secretion. The $M$. latior eggs were on average $1.63 \pm 0.15 \mathrm{~mm}$ long and $0.55 \pm 0.06 \mathrm{~mm}$ wide $(\mathrm{n}=66$, measured at the widest diameter). M. latior eggs were larger than those of $M$. cassununga (Ihering), which measured 1.36 $\mathrm{mm}$ long and $0.48 \mathrm{~mm}$ wide and $M$. cerberus styx Richards, which were $1.13 \mathrm{~mm}$ long and 0.43 wide (Giannotti \& Fieri, 1991; Giannotti \& Silva, 1993; Giannotti, 2006a).

The larval stage showed five instars (Fig. 1), as found in M. cassununga (Giannotti \& Fieri, 1991), M. drewseni Saussure (Giannotti \& Trevisoli, 1993) and M. cerberus styx (Giannotti, 2006a). The average width of the head capsule of the different instars was as follows: larva I was $0.53 \pm 0.09$ $\mathrm{mm}$, larva II, $0.88 \pm 0.10 \mathrm{~mm}$, larva III, $1.22 \pm 0.10 \mathrm{~mm}$, larva $\mathrm{IV}, 1.51 \pm 0.02 \mathrm{~mm}$ and larva $\mathrm{V}, 1.78 \pm 0.09 \mathrm{~mm}$. The average growth rate was 1.37, in agreement with Dyar's rule (Wigglesworth, 1965). Raposo-Filho (1981) and Silva (1984) reported the occurrence of only four larval instars in M. extinctus Zikán and $M$. atramentarius Zikán respectively.

The species has only one lobe on the first abdominal segment, unlike $M$. drewseni (Giannotti \& Trevisoli, 1993). $M$. latior presented a vestigial lobe in third instar larvae, emergent in fourth instar, and fully developed in fifth instar larvae (Fig 2).

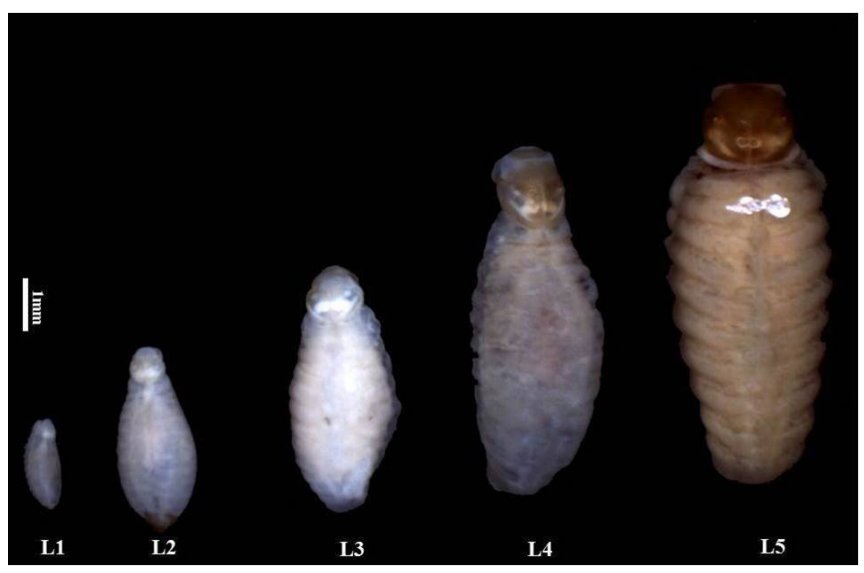

Fig 1. Dorsal view of larval instars from Mischocyttarus latior (Fox) (Hymenoptera: Vespidae): L1 - L5 $1^{\circ}$ to $5^{\circ}$ instar larvae.

\section{Development of Immature Stages}

The mean total duration of the immature stages (from egg laying to adult emergence), was $67.38 \pm 9.41$ days. This duration was longer than the total duration of the immature stages of other studied species, which showed values from 46.1 to 65.9 days (Table 1 ).

Previous studies showed that the average duration of eggs in eight other Mischocyttarus S. species ranged from 11.1 to 16.1 days (Table 1 ). These values were similar to the values we found for $M$. latior (Table 1). The average duration of the larvae of the other eight species ranged from 16.1 to 34.7 days (Table 1), while the average larval stage in $M$. latior was longer at 36.88 days, a value similar to those found in $M$. drewseni and M. cassununga. The average duration of $M$. latior pupae was closer to those found in $M$. atramentarius Z., M. extinctus Z., M. labiatus (F.), M. cassununga and $M$. mexicanus Saussure (Litte, 1977; 1981; Raposo-Filho, 1981; Silva, 1984; Giannotti \& Fieri, 1991). The average duration

Table 1. Comparative data on the duration of the developmental stages of immature individuals of nine species of the genus Mischocyttarus so far studied.

\begin{tabular}{|c|c|c|c|c|c|c|}
\hline \multirow[t]{2}{*}{ Species } & \multirow{2}{*}{$\begin{array}{c}\text { Location (State } \\
\text { and Country) }\end{array}$} & \multicolumn{4}{|c|}{$\begin{array}{l}\text { Average Duration (in days) of } \\
\text { Development Stages }\end{array}$} & \multirow[t]{2}{*}{ References } \\
\hline & & egg & larva & pupa & total & \\
\hline Mischocyttarus cassununga I. & SP, Brazil & 13.20 & 32.60 & 15.60 & 61.20 & Giannotti and Fieri (1991) \\
\hline Mischocyttarus cerberus styx (R.) & SP, Brazil & 11.27 & 31.90 & 19.80 & 61.70 & Giannotti, (2006b) \\
\hline \multirow[t]{2}{*}{ Mischocyttarus drewseni $\mathrm{S}$. } & PR, Brazil & 11.30 & 34.70 & 19.90 & 65.90 & Dantas-de-Araújo (1980) \\
\hline & SP, Brazil & 15.10 & 26.50 & 18.90 & 58.00 & Giannotti and Trevisoli (1993) \\
\hline Mischocyttarus extinctus Z. & RJ and MG, Brazil & 11.40 & 20.60 & 16.80 & 48.80 & Raposo-Filho (1981) \\
\hline Mischocyttarus flavitarsis B. & Arizona, USA & 14.10 & 23.10 & 19.70 & 56.90 & Litte (1979) \\
\hline
\end{tabular}




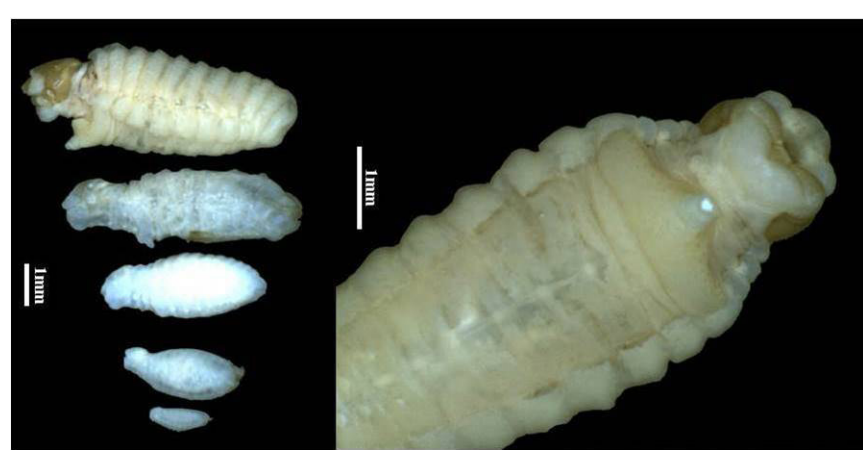

Fig 2. A - Lateral view of $1^{\circ}$ to $5^{\circ}$ instar larvae of Mischocyttarus latior (Fox) (Hymenoptera, Vespidae); B - Detail of the lobe in the first abdominal segment of $5^{\circ}$ instar larva.

of the pupal stage of the other eight Mischocyttarus species ranged from 14.8 to 19.9 days (Table 1). At this stage a smaller variation in duration was observed between species.

The only significant seasonal difference in $M$. latior immature duration was found in larvae $(\mathrm{H}=113.615, \mathrm{p}=$ 0.000 , d.f. $=3)($ Table 2$)$. These results suggest that warmer temperatures (spring and summer) cause $M$. latior individuals to mature faster on average especially during the larval stage (Table 2). Litte (1979) conducted a study in the American Southeast (temperate climate) and found that the average total duration of the immature stages of $M$. flavitarsis also varied according to the months of the year, as well as in the spring and summer seasons, when these colonies develop. In Brazil, Giannotti and Machado (1994) also found that there is seasonal variation in the duration of the immature stages of Polistes lanio lanio. There is a tendency for the duration of the immature stages to shorten when there is an increase in temperature, as observed for M. drewseni (Jeanne, 1972; Dantas-de-Araújo, 1980; Giannotti \& Trevisoli, 1993). Temperature seems to also have a strong influence on the maturation time of eggs of these insects. The eggs of $M$. cassununga showed a longer development time in the cold season (Giannotti \& Fieri, 1991).
The data on duration of immature stages were also analyzed with respect to the nest position occupied by immatures (Table 3). In the center (seven oldest cells) of the nest, the mean duration of eggs was $13.24 \pm 5.24$ days (6-29), larvae, $28.54 \pm$ $16.82(12-92)$ and pupae, $15.41 \pm 3.51$ (7-26), (total $57.19 \pm$ 8.52 days ). In the other remaining (i.e. newer or "peripheral") cells the mean duration of eggs was $14.28 \pm 5.55$ days (6-29), larvae, $38.86 \pm 18.25$ (11-92) and pupae, $16.53 \pm 4.54$ (9-26), (total $69.67 \pm 11.90$ days). Tests indicated that there was no significant difference between the maturation times of eggs $(\mathrm{U}=13431.5, \mathrm{p}=0.170$, d.f. $=1)$ or in the duration of the pupae $(U=3137.0, p=0.349$, d.f. $=1)$. However, a significant difference was found in the mean duration of larvae $(U=$ $2109.0, \mathrm{p}=0.018$, d.f. $=1$ ).

Our findings suggest that the larvae localized in cells which occupy a central position in the nest usually receive a larger amount of food from the adults. Similar results were also reported by West-Eberhard (1969) in Polistes canadensis (L.). It is possible to suggest two (non-mutually exclusive) explanations for the observed differences between the duration of development at the center and periphery of nests. The center of the nest is usually the first place where foragers arrive after collection. Therefore, the returning foragers usually begin by feeding the central larvae and often there is little or no food for the larvae located to the periphery. Another possibility is that due to their position in the comb the temperature of these first seven cells is more stable than that of the cells on the periphery. This would explain the shorter development time of the eggs and pupae, which do not depend on the food provided by forgers for their development.

The Fig 3 shows the data of the average duration of immature stages of $M$. latior, analyzed in relation to the stages of colony development (pre- and post-emergence). Results of the Mann-Whitney $U$ test indicated that there were significant differences in the duration of the immature stages, with quicker stages in the pre-emergence colonies: egg $(\mathrm{U}=5168.0, \mathrm{p}=$ 0.000 , d.f. $=1)$, larva $(U=1273.5, p=0.000$, d.f. $=1)$ and

Table 2. Average duration (in days) of the developmental stages of immature individuals of Mischocyttarus latior (Fox) (Hymenoptera: Vespidae), in relation to seasons and climatic factors.

\begin{tabular}{|c|c|c|c|c|c|c|}
\hline \multirow{2}{*}{ Season } & \multicolumn{3}{|c|}{ Average duration (in days) of immature stages } & \multicolumn{3}{|c|}{ Climatic Factors (mean values) } \\
\hline & egg & larva & pupa & $\begin{array}{c}\text { Temperature } \\
\left({ }^{\circ} \mathrm{C}\right) \\
\end{array}$ & $\begin{array}{l}\text { Rainfall } \\
(\mathrm{mm})\end{array}$ & $\begin{array}{l}\text { Relative humidity } \\
(\%)\end{array}$ \\
\hline $\begin{array}{c}\text { Spring } \\
\text { (September }- \text { November) }\end{array}$ & $14.18 \pm 5.54$ & $22.58 \pm 6.82$ & $15.98 \pm 2.49$ & 24.01 & 107.55 & 64.40 \\
\hline $\begin{array}{c}\text { Summer } \\
\text { (December - February) }\end{array}$ & $14.52 \pm 5.92$ & $19.63 \pm 4.40$ & $15.41 \pm 3.62$ & 25.00 & 347.06 & 75.71 \\
\hline $\begin{array}{c}\text { Autumn } \\
\text { (March - May) }\end{array}$ & $13.16 \pm 5.15$ & $38.84 \pm 13.93$ & $16.88 \pm 4.99$ & 21.80 & 95.58 & 75.04 \\
\hline $\begin{array}{c}\text { Winter } \\
\text { (June - August) }\end{array}$ & $14.83 \pm 5.63$ & $44.78 \pm 15.98$ & $17.40 \pm 4.94$ & 18.67 & 10.41 & 67.53 \\
\hline Mean total Duration & $14.08 \pm 5.50$ & $36.88 \pm 17.98$ & $16.42 \pm 4.77$ & 22.37 & 140.14 & 70.67 \\
\hline
\end{tabular}


Table 3. Average duration (in days) of the developmental stages of immature individuals of Mischocyttarus latior (Fox) (Hymenoptera: Vespidae), raised in the first seven cells constructed and in the other nest cells.

\begin{tabular}{ccccccc}
\hline \multirow{2}{*}{ Stage } & \multicolumn{3}{c}{ Length of Mischocyttarus latior immatures } \\
\cline { 2 - 7 } & \multicolumn{2}{c}{ First seven nest cells } & \multicolumn{3}{c}{ Other nest cells } \\
& Mean & S.D. & Range & Mean & S.D. & Range \\
\hline \multirow{2}{*}{ Egg } & 13.24 & 5.24 & $(6-29)$ & 14.28 & 5.55 & $(6-29)$ \\
Larva & 28.54 & 16.82 & $(12-92)$ & 38.86 & 18.25 & $(11-92)$ \\
Pupa & 15.41 & 3.51 & $(7-26)$ & 16.53 & 4.54 & $(9-26)$ \\
\hline Total & 57.19 & 8.52 & - & 69.67 & 11.90 & - \\
\hline
\end{tabular}

pupa $(U=2181.0, p=0.020$, d.f. $=1)$. This fact is important for colony survival as it shortens the period when the founder remains alone in the nest, allowing the swift emergence of the colony workers. Jeanne (1972) also found that maturation of larval stages in $M$. drewseni colonies was quicker in the preemergence stage. According to a study conducted by Silva (1984), the duration of eggs, larvae and pupae, also varied according to the stage of colony development (pre and post-emergence).

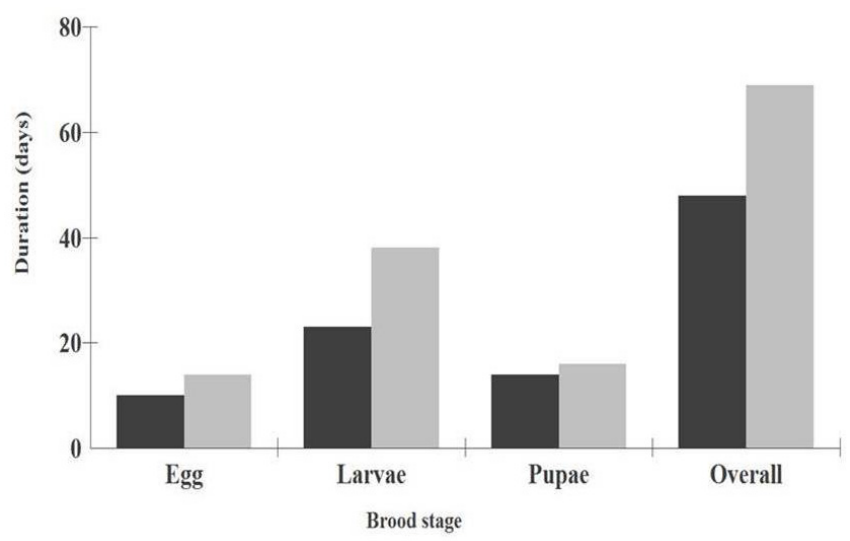

Fig 3. Average duration (in days) of the developmental stages of immature individuals of Mischocyttarus latior (Fox) (Hymenoptera, Vespidae), in pre-emergent (dark grey bars) and post-emergent (light grey bars) colonies.

\section{References}

Dantas-de-Araújo, C. Z. (1980). Bionomia e comportamento social comparado de Mischocyttarus drewseni drewseni de Saussure, 1987, nas regiões subtropical (Curitiba, PR) e tropical (Belém, PA) do Brasil (Hymenoptera, Vespidae). Curitiba: UFPR, 110p.

Elpino-Campos, A., Del-Claro, K. \& Prezoto, F. (2007). Diversity of Social Wasps (Hymenoptera, Vespidae) in Cerrados fragments of Uberlândia, Minas Gerais State, Brazil. Neotropical Entomology, 36: 685-692. doi: 10.1590/S1519566X2007000500008

Giannotti, E. (2006a). Caracterização morfológica dos estágios imaturos e número de ínstares larvais da vespa social Mischocyttarus cerberus (Hymenoptera: Vespidae). In: Resumos do XXI Congresso Brasileiro de Entomologia. Recife, PE. p. 354.
Giannotti,E. (2006b). Fatores que afetam o tempo de desenvolvimento dos estágios imaturos da vespa social Mischocyttarus cerberus (Hymenoptera: Vespidae). In: Resumos do XXI Congresso Brasileiro de Entomologia. Recife, PE. p. 354.

Giannotti,E. \& Fieiri, S.R. (1991). On the brood of Mischocyttarus (Monocyttarus) cassununga (Ihering, 1903) (Hymenoptera, Vespidae). Revista Brasileira de Entomologia, 35: 263-267.

Giannotti, E., Machado, V.L.L. (1994). The seazonal variation of brood stages duration of Polistes lanio (Fabricius, 1775) (Hymenoptera, Vespidae). Naturalia, 19: 97-102.

Giannotti, E. \& Silva, C.V. (1993). Mischocyttarus cassununga (Hymenoptera, Vespidae): external morphology of the brood during the post-embrionic development. Revista Brasileira de Entomologia, 37: 309-312.

Giannotti, E. \& Trevisoli, C. (1993). Desenvolvimento pósembrionário de Mischocyttarus drewseni Saussure, 1857 (Hymenoptera, Vespidae). Insecta, 2: 41-52.

Jeanne, R.L. (1972). Social biology of the neotropical wasp Mischocyttarus drewseni. Bulletin of the Museum of Comparative Zoology, 144: 63-150.

Lima, A.C.O., Castilho-Noll, M.S.M., Gomes, B. \& Noll, F. B. (2010). Social Wasp Diversity (Vespidae, Polistinae) in a Forest Fragment in the Northeast of São Paulo State Sampled with Different Methodologies. Sociobiology, 55: 613-626.

Litte, M. (1977). Behavioral ecology of the social wasp Mischocyttarus mexicanus. Behavioral Ecology and Sociobiology, 2: 229-246. doi: 10.1007/BF00299737

Litte, M. (1979).Mischocyttarus flavitarsis in Arizona: social and nesting biology of a Polistine wasp. Z. Tier Psychol., 50: 282-312. doi: 10.1111/j.1439-0310.1979.tb01033.x

Raposo-Filho, J.R. (1981). Biologia de Mischocyttarus (Mischocyttarus) extinctus Zikán, 1935 (Polistinae-Vespinae). Rio Claro: IBUNESP, 110p.

Richards, O.W.(1978). The social wasps of the Americas excluding the Vespinae. London: British Museum (Natural History), 580p.

Siegel, S. \& Castellan, N.J. (2006). Estatística Não Paramétrica para as Ciências do Comportamento. São Paulo: Artmed-Bookman, 448p.

Silva, M.N. (1984). Aspectos do desenvolvimento e do comportamento de Mischocyttarus (Kappa) atramentarius Zikan, 1949 (Hymenoptera, Vespidae). Rio Claro: IBUNESP, 151p.

Strassmann, J.E. \&Orgren, M.C.F. (1983). Nest Architectures and brood development times in the paper wasp, Polistes exclamans (Hymenoptera, Vespidae). Psyche, 90: 237-248. doi: $10.1155 / 1983 / 32347$

West-Eberhard, M.J. (1969). The social biology of polistine wasps. Miscellaneous Publications, 140: 1-101.

Wigglesworth, V.B. (1965). The principles of insect physiology. London: Methuen, 741p. 